\title{
DETERMINAÇÃO DO SEXO DE EMBRIÕES BOVINOS PRODUZIDOS IN VITRO: UMA REVISÃO DE MÉTODOS COM ÊNFASE PARA A PCR
}

\author{
(Sexing of in vitro produced bovine embryos: A review of methods with emphasis on PCR)
}

\author{
RUFINO, F.A. ${ }^{1}$; SENEDA, M.M. ${ }^{2}$; ALFIERI, A.A. ${ }^{3}$
}

1Aluna do Programa de Pós-graduação em Ciência Animal (Área de concentração: Sanidade Animal; Nível: Mestrado), Centro de Ciências Agrárias (CCA), Universidade Estadual de Londrina (UEL);

'2Laboratório de Reprodução Animal, Depto. de Clínicas Veterinárias, CCA, UEL;

${ }^{3}$ Laboratório de Virologia Animal, Depto. de Medicina Veterinária Preventiva, CCA, UEL, Campus Universitário - Caixa Postal 6001, CEP 86.051-990, Londrina, Paraná, (Bolsista CNPq).

\begin{abstract}
RESUMO - O desenvolvimento de novas biotécnicas em reprodução animal tem proporcionado incrementos significativos no padrão genético de bovinos em todo o mundo. A produção in vitro (PIV) de embriões bovinos ocasionou um salto de qualidade na tecnologia da produção de embriões. Embora a PIV seja uma técnica consolidada, alguns estudos têm demonstrado uma desproporção no sexo de embriões nascidos, onde a porcentagem de embriões machos tem sido maior do que a teoricamente esperada de $50 \%$ para cada um dos sexos. Esse inconveniente abriu a perspectiva para o desenvolvimento de métodos para a determinação do sexo de embriões bovinos antes da transferência, uma vez que os produtos do sexo feminino são economicamente mais valorizados. A presente revisão abordará as vantagens e desvantagens dos principais métodos invasivos e não-invasivos, avaliados quanto ao seu potencial de determinação do sexo de embriões bovinos, com ênfase para a PCR que é a técnica que tem apresentado os melhores resultados.
\end{abstract}

Palavras-chave: bovino, fertilização in vitro, sexagem, PCR.

\begin{abstract}
The development of new animal reproduction biotechniques has been provided the obtaining of genetic improvement in cattle herds around the world. Recently, the ascension of the in vitro production (IVP) of bovine embryos provided important development in the technology of bovine embryos. Although being a consolidated technique, some studies show disproportion between the sexes of calves born by means of IVP, being the percentage of males higher than the theoretically expected rate of $50 \%$ for each sex. This inconvenient opened the perspective for the development of methods for sex determination for the embryos before the transference, once the production of females is desirable in economic terms. This revision will approach the advantages and disadvantages of the invasive and non-invasive methods developed for the sex determination in bovine embryos, with emphasis for PCR assay that is the technique that displays the best results.
\end{abstract}

Key-words: cattle, in vitro fertilization, sexing, PCR.

\section{Produção in vitro de embriões bovinos}

Os avanços significativos na reprodução animal assistida, observados nos últimos anos, têm possibilitado a utilização e a disseminação de animais geneticamente superiores. O desenvolvimento de biotécnicas da reprodução como a produção in vitro (PIV) de embriões bovinos otimizou o aproveitamento de oócitos, contribuindo com o incremento na produção de embriões. Com isso, obteve-se aumento no potencial de exploração do sistema reprodutivo das fêmeas, proporcionando acréscimo no número de descendentes (BLONDIN et al., 2002).

Devido ao grande potencial e rapidez para a multiplicação de descendentes de animais geneticamente superiores, quando comparada a outras biotécnicas, a PIV de embriões bovinos tem-se revelado uma biotécnica de grande importância para os programas de melhoramento genético animal (CAMARGO et al., 2003). Embora essa técnica venha sendo estudada desde 1878 em coelhos e em outros animais de laboratório, estudos mais específicos na espécie bovina somente ocorreram no início da década de 1960. BRACKETT et al. (1982) relataram o nascimento do primeiro bezerro obtido pela PIV a partir de oócitos ovulados, e LU et al. (1988) descreveram a obtenção de gestação a partir de um embrião produzido por um processo totalmente in vitro.

Apesar do grande sucesso da técnica ainda são relatados alguns problemas tais como: i) distócias, que tem como causa o maior peso do bezerro ao nascer ("síndrome do bezerro grande"); ii) abortamentos; iii) gestações prolongadas; iv) malformações congênitas e v) elevada taxa de mortalidade neonatal (HASLER et al., 1995; van WAGTENDONK-de LEEUW et al., 1998; 2000).

Vários estudos têm também demonstrado desvio na proporção macho-fêmea de embriões produzidos in vitro, com a porcentagem de embriões machos superior à proporção teoricamente esperada de $50 \%$ para cada um dos sexos (GUTIERREZ-ADÁN et al., 1996; 2001; van WAGTENDONK-de LEEUW et al., 2000).

A diferença no tempo de desenvolvimento dos embriões de acordo com o sexo parece influenciar a 
desproporção entre machos e fêmeas. Supõe-se que a seleção de blastocistos em estádios mais avançados do desenvolvimento favorece a escolha de machos uma vez que esses, durante os oito primeiros dias após a fertilização in vitro (FIV), desenvolvem-se mais rapidamente quando comparados aos embriões do sexo feminino (AVERY et al., 1991). Esse desenvolvimento precoce poderia ocorrer devido às condições de cultivo dos embriões. O uso de soro fetal bovino no cultivo, com alta concentração de glicose, parece acelerar 0 desenvolvimento dos machos e retardar o das fêmeas (GUTIERREZ-ADÁN et al., 2001). Dentre os fatores relacionados com a diferença na proporção entre os sexos, pesquisas têm sugerido também o método de preparação dos espermatozóides na FIV (RHEINGANTZ, 2000). Portanto, a seleção dos embriões no momento da transferência para as receptoras poderia implicar em maior número de produtos do sexo masculino.

A maior freqüência de machos nos produtos provenientes da PIV é altamente indesejável. O impacto de um único touro sobre um plantel é bastante grande e isso exige extremo rigor na seleção de touros para a colheita de sêmen. Como a produção de gametas é constante, o número de machos com alto potencial zootécnico, necessário em um rebanho, é bem menor em relação às fêmeas. Como a probabilidade de um bezerro tornar-se doador de sêmen é baixa, esses aspectos justificam a desvalorização dos produtos do sexo masculino. Em relação às fêmeas, toda bezerra oriunda de um acasalamento bem planejado é, potencialmente, uma futura doadora. Isto implica em menor risco quanto ao investimento nos animais desse sexo, justificando assim a maior valorização dos produtos do sexo feminino.

A falta de receptoras em número e qualidade suficientes e a ineficiência atual da criopreservação dos embriões produzidos in vitro, também são aspectos a serem considerados quando se avalia a desproporção entre os sexos dos embriões obtidos com a PIV. Praticamente todos os embriões produzidos in vitro são transferidos a fresco. Assim, na inexistência de receptoras para todos os embriões, é comum o descarte daqueles menos adiantados quanto ao desenvolvimento. De acordo com a hipótese de que embriões do sexo feminino apresentam tendência de desenvolvimento mais lento, na prática, pode-se confundir pior qualidade do embrião com desenvolvimento atrasado e, conseqüentemente, descartar justamente os embriões mais valorizados.

\section{Identificação do Sexo de Embriões Bovinos Pré-Implantação}

A diferenciação sexual nos bovinos, assim como nos outros mamíferos, começa na fecundação com a diferenciação do conteúdo cromossômico. O embrião do sexo feminino possuirá dois cromossomos $X$ enquanto o embrião de um macho possuirá um cromossomo $\mathrm{X}$ e um cromossomo $\mathrm{Y}$.

A possibilidade de seleção do sexo, previamente à transferência dos embriões, apresenta grande interesse econômico principalmente devido à multiplicação de animais do sexo desejado. Com o advento da transferência comercial de embriões a partir da década de 1970, a determinação seletiva do sexo dos animais antes da transferência tem sido uma meta almejada pela indústria animal (THIBIER e NIBART, 1995). No entanto, somente no início da década de 1990 a determinação do sexo de embriões bovinos prétransferência foi introduzida como uma biotécnica comercialmente significativa (BREDBACKA, 2001).

Vários métodos têm sido utilizados para a identificação do sexo dos embriões. De acordo com o procedimento de secção, perfuração e penetração da zona pelúcida (ZP), esses métodos podem ser classificados como não-invasivos e invasivos.

\section{Métodos Não-Invasivos}

Os métodos não-invasivos são considerados ideais, pois mantém a integridade do embrião, reduzindo os prejuízos na transferência e posterior implantação. Além disso, deve-se considerar também o baixo custo e a facilidade de interpretação dos resultados.

Métodos imunológicos: Os métodos imunológicos são utilizados na identificação do sexo de embriões pela detecção de um antígeno de superfície celular Yespecífico (antígeno $\mathrm{H}-\mathrm{Y}$ ), cuja expressão é controlada por um gene presente no cromossomo $Y$ dos mamíferos. O antígeno $\mathrm{H}-\mathrm{Y}$ é um antígeno de histocompatibilidade, identificado pela primeira vez em camundongos do sexo feminino, após a rejeição de enxertos de pele provenientes de machos da mesma linhagem sangüínea. No entanto, embora o termo "antígeno $\mathrm{H}$-Y" tenha sido originalmente aplicado a um antígeno de rejeição, o uso desse termo freqüentemente inclui antígenos encontrados somente em células de machos e que induzem a formação de anticorpos séricos (HASELTINE e OHNO, 1981).

A citotoxicidade e a imunofluorescência indireta (IFI) são dois métodos utilizados para a detecção do antígeno $\mathrm{H}-Y$ em embriões. Em ensaios citotóxicos os embriões que expressam esse antígeno apresentam lise celular ou cessam o desenvolvimento, sendo classificados como machos (WATCHEL, 1984). WHITE et al. (1982) identificaram o sexo de 1000 embriões murinos de 8-16 células por meio da citotoxicidade. Após a transferência dos embriões viáveis, 86\% (50/58) dos animais nascidos eram fêmeas. No entanto, o inconveniente desse método é a destruição dos embriões machos.

$\mathrm{Na}$ IFI são utilizados anticorpos anti-H-Y, monoclonais ou policlonais, conjugados com o isotiocianato de fluoresceína. As células portadoras desse antígeno podem ser visualizadas por meio de microscopia de fluorescência. BOOMAN et al. (1989) realizaram a IFI utilizando anticorpos monoclonais. Embora a identificação dos 
Determinação do sexo de embriões bovinos produzidos in vitro: uma revisão de métodos com ênfase para a pcr

machos e das fêmeas tenha sido possível, a avaliação da fluorescência foi subjetiva devido aos sítios inespecíficos de ligação dos anticorpos com as células dos embriões, alcançando apenas $77 \%$ de acurácia. Uma vantagem encontrada nessa técnica, em contraposição à citotoxicidade, é a preservação dos embriões machos.

Embora os métodos de detecção do antígeno $\mathrm{H}-\mathrm{Y}$ sejam simples e rápidos, a acurácia é insatisfatória (BREDBACKA, 1998). Esses métodos também não têm demonstrado repetibilidade e possuem reduzida aplicação quando a determinação do sexo de embriões é realizada com propósitos comerciais.

Métodos bioquímicos: Devido à presença de dois cromossomos $X$ nas células das fêmeas de mamíferos e para manter o número equivalente de genes entre os sexos no início do estádio embrionário, um dos cromossomos $X$ da fêmea é inativado em cada célula. Embora não se tenha certeza do momento exato da inativação do cromossomo $X$, estudos têm sugerido um breve período entre a ativação do genoma embrionário e a inativação de um dos cromossomos X. Por esse motivo, no início do desenvolvimento, tanto a concentração celular quanto a atividade de algumas enzimas ligadas ao cromossomo $X$ podem ser duas vezes maiores nos embriões fêmeas em comparação aos machos. Com isso, a mensuração da concentração celular e/ou da atividade das enzimas ligadas ao cromossomo $X$ indica 0 dobro da atividade quando comparada com as enzimas autossômicas. Essa maior atividade pode ser utilizada para a identificação dos embriões do sexo feminino (MC EVOY, 1992).

Com base nessa hipótese, WILLIAMS (1986) identificou o sexo de embriões murinos por meio da atividade da enzima glicose-6-fosfato desidrogenase (G6PD) e obteve eficiência de 64\%. MONK e HANDYSIDE (1988) mensuraram a atividade da fosforribosil hipoxantina transferase (FHT), outra enzima ligada ao cromossomo X, e obtiveram $91 \%$ de acurácia para as fêmeas e $100 \%$ para os machos.

O principal fator que inviabiliza a aplicação comercial dos métodos que se baseiam na determinação da concentração celular e/ou da atividade das enzimas ligadas ao cromossomo $\mathrm{X}$ é a alta taxa de mortalidade embrionária, sugerindo toxicidade da reação para os embriões (WILLIAMS, 1986). Adicionalmente, essa técnica exige o conhecimento exato do período de inativação do cromossomo $X$, bem como a idade exata dos embriões no momento da análise pois as enzimas monitoradas podem resultar da tradução do RNA mensageiro materno estocado no embrião e não da transcrição do genoma embrionário, levando a resultados errôneos (MC EVOY, 1992).

\section{Métodos Invasivos}

Os métodos mais precisos para a determinação do sexo são invasivos, isto é, requerem a realização de uma biópsia de células dos embriões. A aplicação dos métodos invasivos torna possível obter taxas de até $100 \%$ na eficiência da determinação do sexo. No entanto, além da dificuldade na manipulação durante o processo de biópsia, devido à característica invasiva esses métodos podem acarretar redução nos índices de gestações (BREDBACKA, 1998).

Métodos citogenéticos: As análises citogenéticas implicam na visualização da cromatina sexual (cromossomo X inativado ou corpúsculo de Barr) ou na identificação dos cromossomos sexuais pela técnica de cariotipagem (BONDIOLI et al., 1989)

Visualização da cromatina sexual: A análise citogenética para a identificação de embriões do sexo feminino por meio da visualização da cromatina sexual, realizada em células de embriões de coelhos com cinco dias de desenvolvimento, foi a primeira técnica utilizada para a identificação do sexo. No entanto, em outras espécies animais, a técnica não obteve o mesmo sucesso devido à dificuldade de visualização da cromatina sexual causada pela natureza granular do citoplasma das células embrionárias (KING, 1984).

Cariotipagem: Posteriormente, fragmentos obtidos por biópsia embrionária foram submetidos à outra técnica citogenética para a identificação do par de cromossomos sexuais $\mathrm{XX}$ ou $\mathrm{XY}$ na fase de metáfase. A identificação do sexo por cariotipagem de células provenientes de biópsia é realizada por meio da utilização de substâncias mitostáticas que atuam paralisando o ciclo celular para posterior análise de placas metafásicas (KING, 1984). HARE et al. (1976) demonstraram a possibilidade da determinação do sexo em biópsias de embriões bovinos com 14 e 15 dias de desenvolvimento. No entanto, a necessidade da utilização de blastocistos mais adiantados, eclodidos e elongados, inviabiliza o uso da técnica em programas comerciais. SINGH e HARE (1980) demonstraram que a média do índice mitótico foi de apenas $9 \%$ quando mórulas de seis dias de desenvolvimento foram submetidas à cariotipagem.

Embora a acurácia dessa técnica seja alta, sua eficiência, avaliada pela proporção de embriões que podem ter o sexo determinado, permanece em níveis insatisfatórios (BREDBACKA, 1998). Na maioria das vezes, somente poucas células estão em divisão e pode haver dificuldade na obtenção de células em metáfases bem expandidas que possibilitem a visualização dos cromossomos sexuais. Devido também ao grande número de células necessárias para a análise, a viabilidade dos embriões é seriamente comprometida (SETIABUDI e GUSTAVSSON, 1991). Ainda como desvantagem, a cariotipagem é um procedimento demorado e que exige grande habilidade para a sua realização. Atualmente, a não ser como método de referência para a verificação da eficiência de outros métodos de identificação do sexo, a cariotipagem não tem sido utilizada rotineiramente. 


\section{Métodos Moleculares}

Os estudos do mapeamento do cromossomo $Y$ proporcionaram o desenvolvimento de sondas de DNA específicas para a determinação do sexo de embriões pré-transferência. As sondas Y-específicas são utilizadas para a marcação de seqüências do cromossomo $Y$ por meio das técnicas de hibridização in situ, hibridização in situ fluorescente (FISH) e dot blot.

Hibridização in situ: A utilização da técnica de hibridização in situ permite a localização de seqüências Y-específicas por meio de marcação radioativa. A hibridização positiva indica a presença do cromossomo $Y$ e permite identificar os embriões machos. COTINOT et al. (1991) desenvolveram e utilizaram uma sonda Yespecífica (BC1.2) para a identificação do sexo em 150 biópsias (10-20 células) de embriões por meio da hibridização in situ, obtendo resultado em 57\% das biópsias. A acurácia da técnica, confirmada por análise citogenética, foi de 95\%. SETIABUDI e GUSTAVSSON (1991) também utilizaram a sonda BC1.2, com marcação radioativa e revelação por auto-radiografia, e obtiveram $100 \%$ de acurácia, confirmada por avaliação direta dos cromossomos. Embora a acurácia dessa técnica seja considerada aceitável, a análise requer longos períodos para as etapas de hibridização (12 a 16 h) e de auto-radiografia (1 a 6 dias). Com isso, é necessário o congelamento ou o abortamento seletivo, com redução da viabilidade comercial da identificação do sexo de embriões bovinos produzidos in vitro.

Hibridização in situ fluorescente (FISH): Uma variação da técnica de hibridização in situ é a FISH, que utiliza como marcadores sondas não-radioativas. Em comparação com a hibridização in situ, o uso de sondas fluorescentes não-radioativas facilita a execução da técnica e possibilita maior sensibilidade. Embora a aplicação esteja difundida para o uso em embriões humanos, existe pouca informação sobre a determinação do sexo em embriões bovinos. GAVIO et al. (2001) analisaram 92 embriões produzidos in vitro por meio de remoção da ZP e posterior desagregação dos blastômeros. A partir da fixação de um ou dois blastômeros, a microscopia de fluorescência revelou 79 núcleos em interfase, com $42(53,2 \%)$ núcleos identificados como machos e 37 $(46,8 \%)$ núcleos com sinais negativos caracterizados como fêmeas. LEE et al. (2004) utilizaram a seqüência BtY2 (GenBank: A18483) em blastômeros individuais e em hemi-embriões produzidos in vitro e obtiveram taxas de coincidência de $96 \%$ na determinação do sexo.

Embora a técnica de FISH alcance resultados satisfatórios existe pouca informação sobre a eficiência da determinação do sexo em células embrionárias provenientes de biópsias (KOBAYASHI et al., 1998). Devido às inúmeras etapas requeridas, a aplicação dessa técnica na rotina é praticamente inviável.
Dot blot: BONDIOLI et al. (1989) realizaram o primeiro ensaio em larga escala para testar a acurácia da determinação do sexo pela técnica de dot blot. Por meio de biópsias em 101 embriões de seis e sete dias de desenvolvimento, congelados / descongelados e transferidos, 91 (90\%) embriões tiveram o sexo determinado. Esses embriões resultaram em 35 (40\%) gestações, com $97 \%$ de acurácia do teste. Os resultados desse estudo experimental, onde foram obtidas taxas aceitáveis de sobrevivência do embrião e excelentes de acurácia, indicaram a possibilidade da aplicação comercial da técnica. Em procedimento subseqüente, utilizado para a transferência comercial de embriões, os autores obtiveram acurácia de $100 \%$ na identificação do sexo em 45 (41\%) gestações produzidas. Apesar dos resultados satisfatórios, alguns fatores como os demorados protocolos de hibridização e a complexidade do ensaio, assim como o uso de isótopos radioativos, inviabilizam o uso comercial da técnica, principalmente em embriões produzidos in vitro (HASLER et al., 2002).

Reação em Cadeia da Polimerase (PCR): A identificação do sexo de embriões por meio de métodos moleculares foi facilitada com o advento da PCR. O primeiro estudo para a determinação do sexo de embriões por meio da utilização da PCR foi realizado por HANDYSIDE et al. (1989) em embriões humanos. Em bovinos, um passo marcante no desenvolvimento da técnica foi a descrição da determinação do sexo pela PCR a partir de biópsias em embriões com seis a sete dias de desenvolvimento (SCHRÖDER et al., 1990).

A PCR amplifica exponencialmente pequenos fragmentos de DNA de regiões Y-específicas. A presença ou a ausência de amplificação da seqüência Y-específica indica o sexo do embrião (SHEA, 1999). A técnica caracteriza-se pelo alto grau de eficiência e acurácia (BREDBACKA et al., 1995; HASLER, 2003), além de ser considerado um procedimento rápido e de fácil realização.

Para a determinação do sexo pela PCR podem ser utilizados embriões em vários estádios de desenvolvimento, desde mórula compacta até blastocisto expandido, e de qualidade excelente a boa, pois esse quesito é um fator crítico sobre os resultados (HASLER et al., 2002). Como método invasivo, a principal desvantagem dessa técnica é a necessidade da remoção de um pequeno número de células embrionárias.

A biópsia é o componente mais crítico e laborioso do procedimento para a determinação do sexo de embriões pela PCR e o seu tamanho é um compromisso entre a eficiência da técnica e a viabilidade do embrião (BREDBACKA, 2001). A orientação da biópsia não tem relevância em uma mórula compacta. Entretanto, em blastocistos a massa celular interna deve permanecer intacta e as amostras devem ser retiradas do trofoblasto. O tamanho da biópsia pode variar entre um único blastômero até aproximadamente $10-30 \%$ da massa celular embrionária. A quantidade de células deve ser 
Determinação do sexo de embriões bovinos produzidos in vitro: uma revisão de métodos com ênfase para a pcr

compatível com a alta eficiência na identificação do sexo e com taxas aceitáveis de gestações (BREDBACKA, 1998; GUTIERREZ-ADÁN et al., 1996).

Os embriões produzidos in vitro são mais frágeis à micromanipulação e mais sensíveis à criopreservação. Essas características constituem-se nos principais obstáculos para o uso difundido da PIV (HASLER et al., 1995). A rapidez na execução da técnica e a possibilidade da determinação do sexo de embriões bovinos frescos, sem a necessidade de criopreservação, é uma das principais vantagens da utilização da PCR em laboratórios de PIV de embriões bovinos.

Os protocolos realizados comercialmente para a determinação do sexo de embriões geralmente envolvem a utilização de uma seqüência de oligonucleotídeos iniciadores (primers) Y-específica em associação com primers direcionados para a amplificação de uma seqüência autossômica bovina (controle interno da reação) caracterizando, dessa forma, a multiplex-PCR. Com a utilização desse sistema foram relatadas excelentes taxas de eficiência (90-95\%) e de acurácia (93-98\%) (THIBIER e NIBART, 1995; SHEA,1999).

A inclusão de uma seqüência autossômica é de grande importância uma vez que a detecção de seqüências específicas em DNA de células de embriões, tanto do sexo masculino quanto feminino, é utilizada como controle da reação que assegura a presença de células no material coletado na biópsia e também podem ser detectados problemas no processo de amplificação. Dessa forma a amplificação de seqüências autossômicas evita resultados errôneos, como "falsasfêmeas", passíveis de ocorrer quando se utiliza apenas primers para a amplificação de fragmentos $\mathrm{Y}$ específicos.

Com a utilização do controle interno, após a análise dos produtos amplificados por meio de eletroforese em gel de agarose e/ou poliacrilamida, nos embriões do sexo masculino são visualizados dois produtos correspondentes às seqüências específicas encontradas no cromossomo $Y$ e no gene autossômico. $A$ ausência do produto relativo ao cromossomo $Y$ caracteriza o embrião como do sexo feminino (BREDBACKA, 1998).

MACHÁTY et al. (1993) identificaram, por meio da multiplex-PCR, o sexo de 87 embriões produzidos in vitro, cinco dias pós-fertilização, utilizando apenas um blastômero removido no estádio de 16-32 células. Do total de embriões, foi possível a determinação do sexo em 83 deles, conferindo à técnica 95,4\% de eficiência.

Alta acurácia foi relatada por BOUSQUET et al. (1999) na determinação do sexo pela multiplex-PCR, de embriões de graus 1 e 2 , produzidos in vitro e biopsiados. A acurácia da técnica, confirmada por meio de avaliação ultra-sonográfica do sexo fetal entre 60 e 65 dias de gestação, foi de $97,4 \%$ com taxa de gestação de 53,4\% (319/597). A taxa de identificação dos sexos diferiu estatisticamente com 56,8\% (1047/1844) de machos e $37,5 \%(691 / 1844)$ de fêmeas.
COSTA et al. (2002) identificaram o sexo de embriões produzidos in vitro nos estádios de mórula e blastocisto. No total de 50 embriões a multiplex-PCR possibilitou a determinação do sexo em 48 , resultando em $96 \%$ de eficiência.

CAMARGO et al. (2003) analisaram, também por meio da multiplex-PCR, 109 embriões inteiros, na fase de blastocisto, produzidos in vitro. Foi possível determinar o sexo de 99 embriões demonstrando eficiência de 90,8\%. Nesse experimento, que visou a avaliação da diferença observada entre os sexos, os embriões machos representaram $59,6 \%$ do total de embriões que tiveram o sexo determinado. LUZ et al. (2000) também determinaram o sexo de embriões inteiros produzidos in vitro utilizando a seqüência macho-específica BC1.2 e a seqüência satélite 1.715 para o controle interno da reação. Do total de 92 blastocistos, 86 (93,5\%) embriões tiveram o sexo determinado pela multiplex-PCR.

Alguns estudos relataram como desnecessária a utilização do controle autossômico uma vez que esse pode também interferir na amplificação da seqüência Y-específica (PEURA et al., 1991; BREDBACKA et al., 1994). No entanto, a eficiência da determinação do sexo de embriões produzidos in vitro encontrada por LOPES et al. (1999) foi de 90\% (34/38) quando a reação de PCR foi realizada sem o controle interno autossômico e de $94 \%$ (48/51) quando, na forma de multiplex-PCR, foram incluídos primers para as seqüências Y-específica e autossômica. No mesmo estudo, a acurácia da técnica, relacionada com o diagnóstico correto do sexo dos animais nascidos foi, respectivamente, de 79\% (15/ 19) e de $100 \%(30 / 30)$ com os dois tipos de reação (PCR e multiplex-PCR). GARCIA (2001), com o objetivo de tornar a PCR mais simples, identificou o sexo de 133 embriões utilizando apenas a seqüência $Y$ específica. Para a avaliação do desempenho da técnica foi aceita a margem de erro de $14 \%$ para as possíveis fêmeas e de $7 \%$ para os machos. A confirmação por ultra-sonografia, ou mesmo após o nascimento dos animais, revelou que a taxa correta de embriões machos obtidos foi de $93,7 \%$ (74/79) e para os embriões classificados como "possíveis" fêmeas foi de apenas $75,9 \%(41 / 54)$.

\section{Considerações Finais}

A seleção do sexo anteriormente à transferência dos embriões bovinos tem gerado interesse tanto por parte de pesquisadores quanto dos pecuaristas que buscam aprimorar a qualidade de seus rebanhos.

Nos últimos anos, os grandes avanços observados em biotécnicas da reprodução como a PIV, possibilitaram o incremento no desenvolvimento de métodos para a identificação do sexo de embriões. Uma metodologia de rotina, que tenha por objetivo a determinação do sexo de embriões deve incluir altas taxas de eficiência e de acurácia, e ser seguida por um processo eficiente na transferência desses embriões, 
além da obtenção de altas taxas de gestações.

Visando a aceitação comercial, a técnica de identificação do sexo deve ser rápida, de fácil realização e de custo aceitável. Nesse contexto, a PCR possui muitas vantagens sobre as demais técnicas, possibilitando assim sua utilização para a determinação do sexo de embriões bovinos em escala comercial.

\section{Agradecimentos}

Os recursos financeiros utilizados para a realização deste trabalho foram obtidos nas seguintes agências de fomento à pesquisa: CNPq, CAPES e Fundação Araucária (FAP/PR).

\section{Referências}

AVERY, B.; MADISON, V.; GREVE, T. Sex and development in bovine in vitro embryo production. Theriogenology, v.35, p.953-963, 1991.

BLONDIN, P.; BOUSQUET, D.; TWAGIRAMUNGU, H.; BARNES, F.; SIRARD, M.A. Manipulation of follicular development to produce developmentally competent bovine oocytes. Biology of Reproduction, v.66, p.38-43, 2002.

BONDIOLI, K.R.; ELLIS, S.B.; PRYOR, J.H.; WILLIAMS, M.W.; HARPOLD, M.M. The use of male-specific chromosomal DNA fragments to determine the sex of bovine preimplantation embryos. Theriogenology, v.31, n.1, p.95-103, 1989.

BOOMAN, P.; KRUIJT, L.; VERRHUIS, R.; HENGST, A.M.; TIEMAN, M.; RUCH, F.E. Sexing bovine embryos with monoclonal antibodies against the $\mathrm{H}-\mathrm{Y}$ antigen. Livestock Production Science, v.23, p.1-16, 1989.

BOUSQUET, D.; TWAGIRAMUNGU, H.; MORIN, N.; BRISSON, C.; CARBONNEAU, G.; DUROCHER, J. In vitro embryo production in the cow: an effective alternative to the conventional embryo production approach. Theriogenology, v.51, p.59-70, 1999.

BRACKETT, R.G.; BOUSQUET, D.; BOICE, M.L.; DONAWICK, W.J.; EVANS, J.F.; DRESSEL, M.A. Normal development following in vitro fertilization in the cow. Biology of Reproduction, v.27, p.147-158, 1982.

BREDBACKA, P. Recent development in embryos sexing and its field application. Reproduction Nutrition Development, v.38, p.605-613, 1998.

BREDBACKA, P. Progress on methods of gene detection in preimplantation embryos. Theriogenology, v.55, p.2334, 2001.

BREDBACKA, P.; VELMALA, R.; PEIPPO, J.; BREDBACKA, K. Survival of biopsied and sexed bovine demi-embryos. Theriogenology, v.41, p.1023-1031, 1994.

BREDBACKA, P; KANKAANPÄÄ, A.; PEIPO, J. PCRsexing of bovine embryos: a simplified protocol. Theriogenology, v.44, p.167-176, 1995.
CAMARGO, L.S.A.; SÁ, W.F.; VIANA, J.H.M.; FERREIRA, A.M.; SERAPIÃO, R.V.; RAMOS, A.A.; MACHADO, M.A.; VALE FILHO, V.R.; ANDRADE, V.J. Identificação do sexo de embriões bovinos fecundados in vitro e cultivados com células do cumulus na presença de soro. Revista Brasileira de Reprodução Animal, v.27, n.3, p.407-409, 2003.

COSTA, L.L.; SILVA, J.C.; DINIZ, P.; CIDADÃO, R. Preliminary report on sexing bovine pre-implantation embryos under the conditions of Portugal. Revista Portuguesa de Ciências Veterinárias, v.97, p.95-98, 2002.

COTINOT, C.; KIRSZEMBAUM, M.; LEONARD, M.; GIANQUINTO, L.; VAIMAN, M. Isolation of bovine Yderived sequence: potential use in embryo sexing. Genomics, v.10, p.646-653, 1991.

GARCIA, J.F. Practical considerations of embryo manipulation: preimplantation genetic typing. Theriogenology, v.56, p.1393-1399, 2001.

GAVIO, D.; FERNANDES, M.B.; VILLA, R.A.; GALERANI, M.A.; MARTELLI, L.R.; LÔBO, R.B. Aplicação do método de FISH para determinação do sexo em embriões zebuínos produzidos in vitro. Revista Brasileira de Reprodução Animal, v.25, n.3, p.404-407, 2001.

GUTIÉRREZ-ADÁN, A.; BEHBOODI, E.; ANDERSON, G.B.; MEDRANO, J.F.; MURRIA, J.D. Relationship between stage of development and sex of bovine IVMIVF embryos cultured in vitro versus in the sheep oviduct. Theriogenology, v.46, p.515-525, 1996.

GUTIÉRREZ-ADÁN, A.; LONERGAN, P.; RIZOS, D.; WARD, F.A.; BOLAND, M.P.; PINTADO, B.; FUENTE, $J$. Effect of the in vitro culture system on the kinetics of blastocyst development and sex ratio of bovine embryos. Theriogenology, v.55, p.1117-1126, 2001.

HANDYSIDE, A.H.; PENKETH, R.M.L.; WINSTON, J.K.; PATTINSON, J.D.A.; DELHANTY, J.D.; TUDDENHAM, E.G.D. Biopsy of human pre-implantation embryos and sexing by DNA amplification. The Lancet, v.333, p.347349, 1989.

HARE, W.C.D.; MITCHELL, D.; BETTERIDGE, K.J.; EAGLESOME, M.D.; RANDALL, G.C.B. Sexing 2-weekold bovine embryos by chromosomal analysis prior to surgical transfer: preliminary methods and results. Theriogenology, v.5, p.243-253, 1976.

HASELTINE, F.P.; OHNO, S. Mechanisms of gonadal differentiation. Science, v.211, p.1272-1278, 1981.

HASLER, J.F. The current status and future of commercial embryo transfer in cattle. Theriogenology, v.79, p.245264, 2003.

HASLER, J.F.; HENDERSON, W.B.; HURTGEN, P.J.; JIN, Z.Q.; MC CAULEY, A.D.; MOWER, S.A.; NEELY, B.; SHUEY, L.S.; STOKES, J.E.; TRIMMER, S.A. Production, freezing and transfer of bovine IVF embryos and subsequent calving results. Theriogenology, v.43, p.141-152, 1995. 
Determinação do sexo de embriões bovinos produzidos in vitro: uma revisão de métodos com ênfase para a pcr

HASLER, J.F.; CARDEY, E.; STOKES, J.E.; BREDBACKA, P. Nonelectrophoretic PCR-sexing of bovine embryos in a commercial environment. Theriogenology, v.58, 1457-1469, 2002.

KING, W.A. Sexing embryos by cytological methods. Theriogenology, v.21, p.7-17, 1984.

KOBAYASHI, J.; SEKIMOTO, A.; UCHIDA, H.; WADA, T.; SASAKI, K.; SASADA, H.; UMEZU M, SATO E. Rapid detection of male-specific DNA sequence in bovine embryos using fluorescence in situ hibridization. Molecular Reproduction and Development, v.51, p.390394, 1998.

LEE, J.H.; PARK, J.H.; LEE, S.H.; PARK, C.S.; JIN, D. Sexing using single blastomere derived from IVF bovine embryos by fluorescence in situ hibridization (FISH). Theriogenology, v.62, p.1452-1458, 2004.

LOPES, R.F.F.; SENNA, J.P.M.; CHIES, J.M.; RODRIGUES, J.L. Pit-stop PCR: an approach to increase final product yield of multiplex PCR. Biotechniques, v.26, p.638-639, 1999.

LU, K.H.; GORDON, I.; CHEN, H.B. Birth of twins after transfer of cattle embryos produced by in vitro techniques. Veterinary Records, v.122, p.540-593, 1988.

LUZ, M.R.; WATANABE, Y.F.; FERRO, J.A.; FERRO, M.I.T.; MAURO, S.M.S.; HOSSEPIAN DE LIMA, V.F.M.; FRANCESCHINI, P.H. Identificação do sexo de embriões bovinos fecundados in vitro pela técnica de PCR multiplex. Brazilian Journal of Veterinary Research and Animal Science, v.37, n.6, p.453-456, 2000.

MACHÁTY, Z.; PÁLDY, A.; CSÁKI, T; VARGA, Z.; KISS, I.; BÁRÁNDI, Z.; VAJTA, G. Biopsy and sex determination by PCR of IVF bovine embryos. Journal of Reproduction and Fertility, v.98, p.467470, 1993.

MC EVOY, J.D. Alteration of sex ratio. Animal Breeding Abstracts, v.60, n.2, p.97-111, 1992.

MONK, M.; HANDYSIDE, A.H. Sexing of preimplantation mouse embryos by measurement of $X$-linked gene dosage in a single blastomere. Journal of Reproduction and Fertility, v.82, p.365-368, 1988.

PEURA, T.; HYTTINEN, J.M.; TURUNEN, M.; JÄNNE, J. A reliable sex determination assay for bovine preimplantation embryos using the polimerase chain reaction. Theriogenology, v.35, p.547-555, 1991.
RHEINGANTZ, M.G.T. Efeito do método de preparação dos espermatozóides e das condições de cultivo sobre a proporção macho:fêmea dos embriões bovinos produzidos in vitro. Pelotas: UFPel, 2000. Tese (Doutorado) - Programa de Pós-graduação em Biotecnologia, Faculdade de Medicina Veterinária, Universidade Federal de Pelotas, Pelotas, 2000.

SCHRÖDER, A.; MILLER, J.R.; THOMSENP.D.; ROSCHLAUD, K.; AVERY, B.; POULSEN, P.H.; SCHMIDT, M.; SCHWERIN, M. Sex determination of bovine embryos using the polymerase chain reaction. Animal Biotechnology, v.1, n.1-2, p.121-133, 1990.

SETIABUDI, R.; GUSTAVSSON, I. Establishment of embryo sexing techniques in Sweden. Reproduction of Domestic Animals, v.26, p.78-81, 1991.

SHEA, B.F. Determining the sex of bovine embryos using the polimerase chain reaction results: a six-year retrospective study. Theriogenology, v.51, p.841-854, 1999.

SINGH, E.L.; HARE, W.C.D. The feasibility of sexing bovine morula stage embryos prior to embryo transfer. Theriogenology, v.14, p.421-427, 1980.

THIBIER,M.; NIBART, M. The sexing of bovine embryos in the field. Theriogenology, v.43, p.71-80, 1995.

van WAGTENDONK-de LEEUW, A.M.; AERTS, B.J.D.; DEN DASS, J.H.G. Abnormal offspring following in vitro production of bovine preimplantation embryos: a field study. Theriogenology, v.49, p.883-894, 1998.

van WAGTENDONK-de LEEUW, A.M.; MULLAART, E.; ROOS, A.P.W.; MERTON, J.S.; DEN DASS, J.H.G; KEMP, B.; RUIGH, L. Effects of different reproduction techniques: Al, MOET or IVP, on health and welfare of bovine offspring. Theriogenology, v.53, p.575-579, 2000.

WATCHEL, S. H-Y antigen in the study of sex determination and control of sex ratio. Theriogenology, v.21, p.18-28, 1984.

WHITE, K.L.; LINDNER, G.M.; ANDERSON, C.B.; BONDURANT, R.H. Survival after transfer of "sexed" mouse embryos exposed to $\mathrm{H}-\mathrm{Y}$ antisera. Theriogenology, v.18, p.655-662, 1982.

WILLIAMS, T.J. A technique for sexing mouse embryos by a visual colorimetric assay of the X-linked enzyme, glucose 6-phosphate dehydrogenase. Theriogenology, v.25, p.733-739, 1986.

Recebido para publicação: $\quad$ 05/01/2006 Aprovado:
20/06/2006 